\title{
IMPLEMENTATION OF OCCUPATIONAL SAFETY AND HEALTH FOR USING SEA TRANSPORTATION (CASE STUDY AT TENGKAYU II PORT OF TARAKAN CITY)
}

\author{
Kresna Febriyanto ${ }^{1 *}$, Suprayitno ${ }^{2}$ \\ ${ }^{1,2}$ Public Health Program, UniversitasMuhammadiyah Kalimantan Timur, Indonesia \\ *E-mail : kresna.kesmas@umkt.ac.id
}

\begin{abstract}
All sea transportation facilities users in the world in general especially in Indonesia always prioritize safety, security and comfort aspects. The ship accidents such as sinking, burning, etc., are problems related to the safety and security of sea transportation. The purpose of this study it was to determine the application of occupational safetyand health inside the speedboat accordance with Ministerial Regulation No. 6 of 2018 concerning Occupational Safety and Health $(\mathrm{OSH})$ in the Ministry of Maritime Affairs and Fisheries.This study used a qualitative method carried out at the port of Tengkayu II, Tarakan City, North Kalimantan were speedboat passengers as the main informants, as well as Transportation Service officers and dock workers as supporting informants. The sampling technique used accidental sampling technique. The results of the study stated that the application of OSH inside the speedboat had not been fully implemented.Passenger awareness is a fundamental cause of the non-implementation of that regulations. One aspect of applying OSH inside the speedboat in accordance with applicable regulations is to use a life jackets while in a speedboat. Passengers only wear life jackets just before leaving when inspected by officers, but will be removed if it is far from the port. Discomfort factor is the main reason why life jackets are not used. In addition, the boat captain's negligence was still found because it did not prioritize the safety of the feeder, and driving was not in accordance with the applicable standard operating procedures.
\end{abstract}

Keywords: Sea Transportation,Speedboat Passengers.

\section{INTRODUCTION}

Transportation in the era of globalization is a very important requirement for the community in supporting all activities and daily routines. Each mode of transportation has its role and capacity in serving passengers. Public transportation which supports the task of the government in its true development effort is the mode of sea transportation. The sea transportation is very important to connect one island to another so that the distribution of goods and passengers from one island to another can run smoothly, so that equitable distribution of development can be carried out and not only concentrated in one region or one island ${ }^{2}$.

The sea transportation users in the world in general especially in Indonesia always prioritize safety, security issues, which are then followed by aspects of affordable costs, speed and timeliness, and comfort aspects. The ship accidents such as sinking, burning, etc., are problems related to the safety and security of sea transportation. Since 2011 until now there have been fluctuations in the development of the number of accidents, on average there has been a 
decrease in the number of accidents by $6.95 \%$ per year, but on the other hand the number of fatalities increased by $46.71 \%$ per year ${ }^{3}$.

The cause of sea accidents in general is due to the factor of excess transportation from the specified transport capacity. In fact, it is not uncommon for shipping service users to force themselves to board a ship even though the ship is full of and hopes to get a place on the ship. Data on shipping accident investigations obtained by the National Transportation Safety Committee (NTSC) during 2010-2016 tended to increase every year.A total of 54 cases of sea accidents in Indonesian territory caused more than 300 deaths and more than 450 injuries. NTSC also said $41 \%$ of ship accidents were caused by human factors and the rest technically. Weather factors have a very small percentage or even almost no accidents that occur due to weather factors. It can be concluded that humans are the most dominant factor in the occurrence of a ship accident ${ }^{4}$. As for the sea in the region ofTarakan, there have been 3 cases of accidents throughout the year ( 1 case of crashing into a tree, 1 case of overturning, and 1 case of contact with another ship) with 15 fatalities..

Predictions about human error involvement have become important issues in the marine transportation industry ${ }^{1}$. The consequences of human error can potentially endanger human life, the marine environment and on-board ship commodities. The number of accidents in 2010 to 2016 was relatively constant and there was no significant decrease. For that the reduction in the number of accidents must be reduced or the number of victims can be reduced to a minimum.It is very important to reduce the number of fatalities and injuries resulting from ship accidents. Therefore, understanding of the passengers and speedboat boat owners is needed to implement occupational health and safety in the speedboat to avoid ship accidents or something undesirable. The purpose of this study was to determine the application of occupational health and safety inside the speedboat in accordance with Ministerial Regulation No. 6 of 2018 concerning Occupational Safety and Health (OSH) in the Ministry of Maritime Affairs and Fisheries.

\section{MATERIAL AND METHOD}

This research used qualitative methods. According to Moleong (2011) qualitative research is aims to explain phenomena profusely through deep data collection. This study does not prioritize population size or sampling, even sampling is very limited. If the data collected is deep and can explain the phenomenon under study, then there is no need to look for other sampling. Qualitative research places more emphasis on the problem of depth (quality) of data rather than the quantity of data ${ }^{5}$.This research was conducted during April and June 2019 at the port of Tengkayu II, Tarakan City, North Kalimantan.

Research subjects in qualitative research are not called respondents. But referred to as a resource, participation or informant as a subject. The sampling technique at the resource persons to be interviewed is done by accidental sampling technique. According to Sugiyono ${ }^{7}$, Accidental Sampling is a sampling technique based on coincidence, ie informants who accidentally meet with researchers can be used as samples.

\section{Method of Collecting Data}

1. Primary Data

Primary data were collected through observation and in-depth interviews with Speedboat passengers at Tengkayu II Port. The supporting informants were Transportation Service officers who guarded around the port. Researchers also used manual books, notes, and recording devicesas supporting tools in this research. 
2. Secondary Data

Data obtained by several sources of information include documents from the Department of Transportation, Port Office (CV. Camfilo) as the manager of the port tengkayu II, scientific books, and research journals that are relevant to this research.

\section{Research Instruments}

1. Interview guidelines, consisting of :

a. Interview guideline namely "A" as Speedboat passengers as key informants, to explore the fulfillment of passenger safety rights in using sea transportation.

b. Interview guideline namely "B" which is a docker as supporting informant who works at the port ofTengkayu II.

c. Interview guideline namely "C" ask to Department Transportation as supporting informants, to explore program information related to the implementation of safety by using sea transportation.

2. Notebook

3. Recording and documentation equipment (handphone\& camera)

\section{Validity and Reliability Test}

Validity and reliability test in qualitative research also known as data validity testing ${ }^{6}$. Testing the validity of the data in this study used triangulation method. The triangulation methodwas done by checking the data that has been obtained through several sources. The results of observations from some of these sources cannot be averaged as in quantitative research, but are described, categorized which views are the same and which views differ from some of the data sources. Data that has been analyzed by researchers and produce a conclusion will be followed by agreement with the source or informant that the conclusion is true ${ }^{5}$.

\section{Data Analysis Technique}

The data analysis model in this study follows the concept given by Milles and Huberman. Miles and Huberman revealed that the activity in quality data analysis was carried out interactively and took place continuously at each stage of the study to completion. Components of data analysis below as:

1. Reduction

Reducing data means summarizing, choosing main things, focusing on important things, looking for themes and patterns, thus the data has been reduced will provide a clearer picture, and make it easier for researchers to do data collection and then data management.

2. Penyajian data/Display data

Presentation of qualitative research data can be done in the form of a brief description, charts, relationships between categories and the others.

3. Verification

The initial conclusions drawn are still temporary and will change if strong evidence was found, which supports the next teap. But if the conclusions raised at an early stage are supported by valid and consistent evidence when the researcher returns to the field to collect data, then the conclusions put forward are credible conclusions.

\section{RESULTS AND DISCUSSION}

Basically, transportation safety is the right of every citizen, which the Government of Indonesia must conduct and protect organizations from safe, orderly, gentle and easily accessible 
transportation. Passengers transported to the destination port must be guaranteed safety. Transportation with guaranteed security services can provide a sense of security and comfort for the passenger or the owner of the goods. Therefore the government in 1999 through presidential decree number 105 of 1999 formed the National Transportation Safety Committee (KNKT) ${ }^{10}$. For this reason, laws and regulations are made to regulate the process of transporting goods or passengers safely to their destination.

The understanding of the application of occupational safety and health aspects inside the speedboat is unknown to the research respondents, both passengers, and the speedboat captain. They only mentioned that it was something that had to be upheld in order to be safe to the destination. But does not specifically mention what are the aspects of occupational safety and health inside the speedboat. If referring to the Minister of Maritime Affairs and Fisheries Regulation No. 6 of 2018 concerning Occupational Safety and Health in the Environment Ministry of Maritime Affairs and Fisheries as below as ${ }^{8}$ :

1. Ensure passengers have worn life jackets before the speedboatboarding

2. Do not smoke during the trip

3. Check the condition and feasibility of the speedboat every day

4. Provides fire extinguisher, first aid kit, and radio communication in the speedboat

5. The speedboat driver (motorist) is assisted by a helper in charge of linking the mine / anchor to the dock, distributing life jackets to passengers, pumping the speedboat engine, adjusting the passenger seat so that it is balanced

6. Speedboat must not exceed passenger capacity

7. Speedboat must be equipped with fog lights installed when it is raining / foggy

8. Motorists reduce the speed of the speedboat while passing through the village / hand in hand with a smaller boat

9. Passengers are prohibited from standing before the speedboat really stops at the dock; and 10. Passengers must fill in attendance (attendance list) at each speedboat.

The results of the interview of researchers to informants of the study stated that aspects of the application of OSH inside the speedboat only wear life jackets, and do not smoke in a speedboat. So they can be sure they have not understood about the application of OSH inside the speedboat. Government regulations as well as laws regarding the application of OSH in speedboats are also not yet fully known by research informants (speedboat passengers). They are not aware that there are laws or regulations governing safety in a speedboat. Meanwhile, supporting informants (speedboat masters) have understood the regulation, but it is lack ofOSH inside the speedboat.

The lack of OSH implementation in speedboats is due to several reasons. The speedboats operating in the port of Tengkayu II, there are 2 types of speedboats. First regular speedboats (have received permission from the port authority, there are official tickets, have a life jacket according to passenger capacity, scheduled departure time every day, even though the speedboat is privately owned). Second isnon-regular speedboats (operating if there are enough passengers, the departure time is not certain, and usually not recorded because there are no official tickets). Regular speedboats will be easily monitored by relevant officers because of scheduled departure times. But for non-regular speedboats, the departure time is flexible according to the number of passengers transported. And usually non-regular speedboats depart on the other side of the port. This makes it difficult for officers to monitor the completeness and safety available on non- 
regular speedboats. Sometimes the number of life jackets on a non-regular speedboat does not match the number of feeders.

The lack of passenger awareness is also one of the reasons why the application of OSH inside speedboat is minimal to be applied. Specifically for regular speedboats, passengers must wear a life jacket before leaving. This applies to every speedboat and is supervised directly by the port officers (police) on duty. If the person does not wear a life jacket, the speedboat is not permitted to leave. Sometimes becomes a debate between passengers, officers, and crew. Based on the observations of researchers and the results of interviews, passengers only wear life jackets before leaving. However, after departing and approximately 50-100 meters from the port and far from the monitoring of officers, the life jacket worn will be removed. Passenger reasons if using a life jacket, it will feel hot and difficult to move. The observation of researchers was also shortly before being released from the port and when inspected by officers, passengers only put a life jacket in front of them without being worn perfectly. If it is known to the officer, the officer simply ignores it. Besides that, some regular speedboats, especially the speedboats which have air-conditioned, were also found by passengers who smoked while traveling to the port of destination. The passenger will come out of the air-conditioned room (a special room for passengers), then smoke. Even though the distance is far from the speedboat engine, still it endangers the safety of all passengers. It is clearly stated in the legislation or government regulation that while smoking a speedboat is forbidden to smoke. Negligence like this is considered to ignore and not comply with regulations set by the government.

Another factor related to the lack of application OSH inside the speedboat is the factor of the captain driving a speedboat that is not according to the rules and tends to be reckless. In addition, non-regular speedboats do not fully apply OSH to speedboats. Researchers observing when using non-regular speedboat services, the captain/motorist speedboat tries to race the speedboat that has overtaken him. This is certainly very dangerous to the safety of passengers on the speedboat. Marine accidents, in general, imply any extraordinary and undesirable event that causes dangerous consequences, endangering lives, property and the environment. Extraordinary events are divided into those that do not cause dangerous consequences, but can cause loss of life, endanger health, damage to the material at sea or land, pollution, and other consequences. About $75-96 \%$ of marine accidents are caused by some human error ${ }^{9}$. Also according to Faturachman, et al. (2008) explained that the human factor was the biggest factor which included: carelessness in running the ship, lack of ability of the crew to master various problems that might arise in the operation of the ship, as well as lack of coordination between the captain and the crew that caused the ship to load excessive ${ }^{10}$. Considering the reasons stated above, all accidents can be minimized if there is a prevention of all parties to prevent the occurrence of ship accidents.

Regarding the security and safety of shipping, it has been regulated by an international agency that manages or handles matters relating to the safety of life, marine assets and environmental sustainability. The institution is called the International Maritime Organization (IMO) which is under the auspices of the United Nations. To ensure the security and safety of shipping, IMO has issued new International Safety Management Code (ISM-Code) regulations. Fulfilling the ISM-Code refers to 13 elements consisting of (1) general elements; (2) environmental safety and protection policies; (3) environmental responsibility and protection; (4) company responsibilities and authority; (5) officers appointed on land; (6) the responsibilities 
and authority of the skipper; (7) resources and labor; (8) development of vessel operating plans; (9) preparedness for emergencies; (10) reporting and analysis of non-conformities, accidents and dangerous events; (11) maintenance of ships and equipment; (12) company verification, review and evaluation; (13) certification, verification and supervision ${ }^{11}$.

\section{REFERENCES}

1. Akyuz, E. \&Celik, M. A hybrid human error probability determination approach: The case of cargo loading operation in oil/chemical tanker ship. Journal of Loss Prevention in the Process Industries (2016).

2. Faturachman, Danny., Muslim, Muswar., Sudrajad, Agung. AnalisisKeselamatanTransportasiPenyeberanganLautdanAntisipasiTerhadapKecelakaanKapa 1 Di Merak-Bakauheni. JurnalTeknikMesinUntirta. (available athttp://mesin.untirta.ac.id/wpcontent/uploads/2015/10/6-Danny.pdf, onJune 24, 2018) (2015).

3. Kadarisman, Muh. KebijakanKeselamatandanKeamananMaritimdalamMenunjangSistemTransportasiLaut. JurnalManajemenTransportasi\&Logistik. (available athttps://www.researchgate.net/publication/319641897_KEBIJAKAN_KESELAMATAN_D AN_KEAMANAN_MARITIM_DALAM_MENUNJANG_SISTEM_TRANSPORTASI_LA UT/fulltext/59b746290f7e9bd4a7fd8128/319641897_KEBIJAKAN_KESELAMATAN_DA N_KEAMANAN_MARITIM_DALAM_MENUNJANG_SISTEM_TRANSPORTASI_LAU T.pdf?origin=publication_detail, on June 24, 2018) (2017).

4. KNKT. Data InvestigasiKecelakaanPelayaranTahun 2010-2016.Jakarta: Media Release KNKT (2016).

5. Moleong, Lexy. J. MetodologiPenelitianKualitatif. Bandung: PT RemajaRosdakarya (2011).

6. Notoatmodjo, Soekidjo. MetodologiPenelitianKesehatan. Jakarta: RinekaCipta (2012).

7. Sugiyono. MetodePenelitianKuantitatif, Kualitatifdan R\&D, Bandung: Alfabeta.dst (2009).
8. Permen
No. 6 tahun
2018.Keselamatan
Dan KesehatanKerjadiLingkunganKementerianKelautan Dan Perikanan (2018).

9. Hanzu-Pazara, R., etc.Reducing of maritime accidents causedby human factors using simulators in training process,Journal of Maritime Research (2008).

10. Faturachman, Dany\& Mustafa, Shariman. Sea Transportation Accident Analysis in Indonesia. Journal of Procedia-Social and Behavior Sciences. (available at http://umpir.ump.edu.my/id/eprint/2459/1/Elsevier_Paper_format_110729_Pattaya.pdfon June 9,2019) (2012).

11. Mandaku, Hanok. SebuahAnalisisTentangSebab-SebabKejadian Kecelakaan Km. PutriAyu Di PerairanPulau Ambon-Maluku.JurnalTeknikIndustri (2012). 